\title{
Effect of lactic acid and steam treatments on Campylobacter jejuni on chicken skin
}

\author{
Guzin Iplikcioglu Cil', Haydar Ozdemir ${ }^{1}$, Bahar Onaran ${ }^{1 *}$, Gorkem Cengiz', Erdi Sen² \\ ${ }^{1}$ Department of Food Hygiene and Technology, Faculty of Veterinary Medicine, Ankara University, Diskapi, Ankara, ${ }^{2}$ Department of Food \\ Hygiene and Technology, Faculty of Veterinary Medicine, Mehmet Akif Ersoy University, Yahsihan, Burdur
}

\section{A B S T R A C T}

\begin{abstract}
Minimization of Campylobacter jejuni contaminations in poultry meats is important for public health. Certain chemical agents and physical processes to be used on carcasses to destroy pathogenic microorganisms. One of the most common used chemical is lactic acid. The bactericidal activity of different concentrations of lactic acid and hot steam on the $C$. jejuni populations on chicken skin samples were determined. Chicken breast skin samples were inoculated with $C$. jejuni and dipped into different lactic acid solutions and hot steam. reduction of $C$. jejuni and $\mathrm{pH}$ values were determined after $0 ., 1 ., 3$. and 5 days of the storage at $4 \pm 1^{\circ} \mathrm{C}$. according to microbiological analysis. Compared with the control group, reductions in $C$. jejuni populations were determined as 1.72 and $2.02 \log$ at $22^{\circ} \mathrm{C}$, as 1.91 and $2.34 \log$ at $54^{\circ} \mathrm{C}$ on day 0 , in $2 \%, 3 \%$ concentrations respectively. On the other hand, beginning from day 0 , bacterial counts reached undetectable $\left(<1.0 \times 10^{2} \mathrm{cfu} / \mathrm{g}\right)$ levels after the decontamination treatments with $4 \% \mathrm{LA}$ for $60 \mathrm{~s}$ at $22^{\circ} \mathrm{C}$ and $54^{\circ} \mathrm{C}$, after the treatments with $2 \%$ LA followed by HS concentrations of $97 \pm 1^{\circ} \mathrm{C}$ for $15 \mathrm{~s}$ and $133 \pm 1{ }^{\circ} \mathrm{C}$ for $3 \mathrm{~s}$. It was determined that decontamination with lactic acid and hot steam application had a significant reduction effect on $C$. jejuni in chicken skin samples and the effect of lactic acid was increased depending on the concentration.
\end{abstract}

Keywords: Campylobacter jejuni; Chicken meat; Decontamination; Hot steam; lactic acid

\section{INTRODUCTION}

Campylobacter jejuni is one of the most common causes of bacterial originated gastroenteritis in humans. Besides, raw or undercooked contaminated poultry meat consumption is primarily responsible for the transmission to humans of the bacteria. Therefore minimization of C.jejuni contaminations in poultry meats is important for public health. C. jejuni is primarily responsible for foodborne gastroenteritis in developed countries such as the USA, Canada, Australia and Japan, particularly in European countries. It is stated that about 9 million cases of campylobacteriosis occur annually in the European Union countries, which causes serious problems in terms of public health. Campylobacter contamination in poultry varies according to the country. Bacteria can easily be transmitted to the chicken carcasses as a result of cross-contamination during the slaughtering process, due to the colonization of bacteria in the intestines from the $3^{\text {rd }}$ week (Hashem and Parveen, 2016; Skarp et al., 2016).
Studies have shown that chicken carcasses are contaminated with C. jejuni at different levels (Hue et al., 2011; Ma et al., 2014; Wieczorek and Osek, 2015). Hue et al. (2011) reported that $C$. jejuni contamination incidence in chicken carcasses was $87.5 \%$. Similarly, Ma et al. (2014) reported that contamination rate in cecum of broiler chickens and carcass samples was $72.5 \%$ and $34.1 \%$ respectively. In another study, C.jejuni contamination percentage in chicken carcasses determined by Wieczorek and Osek (2015) was found between $36.3 \%$ and $70.5 \%$. In studies conducted in Turkey, C. jejuni contamination in neck skin and chicken carcass were $74.8 \%$ and 86.25 , respectively (Koluman, 2010; Savaçı and Ozdemir, 2006).

Although the European Union's (EU) food legislation does not permit use of chemical agents or physical processes for decontamination in poultry carcasses, the use of lactic acid in cattle carcasses is permitted by directive EU Directive $101 / 2013$ published in 2013. In Turkey, similar directives are also adapted in legislation (Anon, 2013).

\footnotetext{
*Corresponding author:

Bahar Onaran, Department of Food Hygiene and Technology, Faculty of Veterinary Medicine, Ankara University, 06110, Diskapi, Ankara. Tel: +90 53463034 56. Fax: +90 31231644 72. E-mail: dr.baharonaran@gmail.com

Received: 11 December 2018; $\quad$ Accepted: 29 January 2019
} 
The US Department of Agriculture Food Safety and Inspection Service (USDA/FSIS) has allowed certain chemical agents and physical processes to be used on carcasses to destroy pathogenic microorganisms at certain stages of slaughtering of cattle, swine and poultry. The most common chemicals used in these applications are organic acids, acidified sodium chloride and trisodium phosphate, whereas hot water and pressurized hot steam applications are used as physical processes (Bolder, 1997; Sofos and Smith, 1998; Oezdemir et al., 2006; Anon, 2015).

Studies conducted by different researchers (Anang et al., 2007; Chaine et al., 2013; Liu et al., 2016) have reported that there are significant declines in the number of pathogens such as C. jejuni, Salmonella spp., Listeria monocytogenes, E. coli 0157:H7 in poultry meat as a result of decontamination with lactic acid at different concentrations and temperatures. Anderson and Marshall (1990) reported that the reduction effect of lactic acid to bacteria counts varies with the concentration and temperature of the lactic acid solution and duration of the treatment. Liu et al. (2016) reported that $1.5 \%$ lactic acid at $50^{\circ} \mathrm{C}$ caused a drop of about 1.88-2.03 log on Clostridium spp. and Pseudomonas fluorescens.

This study was conducted to determine the reduction effect of lactic acid and hot steam applications on C. jejuni population and the difference between lactic acid at different concentrations and temperatures and hot steam applications at a temperature of about $97 \pm 1^{\circ} \mathrm{C}$ and $133 \pm 1{ }^{\circ} \mathrm{C}$

\section{MATERIALS AND METHODS}

\section{Bacterial inoculum preparation}

Campylobacter jejuni ATCC 33291 (Oxoid, Hampshire, U.K.) was used as a stock strain for the preparation of the inoculum. Stock strain was plated onto Blood Free Campylobacter Selective Agar Base (CCDA-Oxoid CM0739, Supplement Oxoid SR0155) and was incubated for $48-72 \mathrm{~h}$ at $42^{\circ} \mathrm{C}$ in microaerobic conditions (Campygen, Oxoid CN025). After the incubation, colonies were transferred into Brain Heart Infusion Broth (Oxoid CM1135) by sterile swab with the volume of $10 \mathrm{~mL}$. The bacterial density of the inoculum was controlled by plating eightfold serial dilutions onto CCD agar base in duplicate, before the inoculation of the chicken breast skin samples. Broth cultures of C. jejuni ATCC 33291 was determined to reach about $9.0 \times 10^{5} \mathrm{cfu} / \mathrm{mL}$.

\section{Sample inoculations}

Chicken breast skin samples were obtained from 50 samples from the whole chicken carcasses purchased from local supermarkets and were transported to the laboratory within $30 \mathrm{~min}$. under refrigerated conditions. From the whole breast skins, samples were excised aseptically with the approximate size of $8 \times 8 \mathrm{~cm}$, and weight about 13-15 g, in the laboratory. Afterwards, the samples were immersed into the suspension that contain freshly prepared C. jejuni at $10^{5} \mathrm{cfu} / \mathrm{mL}$ level, for $5 \mathrm{~min}$ in sterile bottles at room temperature. After inoculation, samples were held in sterile bags for $30 \mathrm{~min}$ at room temperature to allow the attachment of bacteria.

\section{Antimicrobial treatment and sampling}

All antimicrobial solutions were prepared freshly before the experiments. The inoculated skin samples were immersed respectively into the antimicrobial solutions of $2 \%(\mathrm{pH} 1.93), 3 \%(\mathrm{pH} 1.86)$ and $4 \%(\mathrm{pH} 1.81)$ lactic acid (LA) (Merck 1.00366.2500) for $60 \mathrm{~s}$ at $22-54^{\circ} \mathrm{C} \pm 1$ and hot steam (HS) $97-133^{\circ} \mathrm{C} \pm 1$ respectively, 15 and $3 \mathrm{~s}$. These concentrations are the most common and economic ones for the treatments. The inoculated samples were divided into seven groups, each containing 10 chicken skin samples and were treated with 7 different applications alone or in combination. Treatment groups were; sterile distilled water; $\left(22-54^{\circ} \mathrm{C}\right) ; 2 \% \mathrm{LA} ; 3 \% \mathrm{LA} ; 4 \% \mathrm{LA}$; HS for $15 \mathrm{~s}$ at $97^{\circ} \mathrm{C} ; 2 \% \mathrm{LA}$ followed by HS for $15 \mathrm{~s}$ at $97^{\circ} \mathrm{C}$; $\mathrm{HS}$ for $3 \mathrm{~s}$ at $133^{\circ} \mathrm{C}$. Following the treatment, the samples were held at room temperature for $5 \mathrm{~min}$, and they were stored at $4^{\circ} \mathrm{C}$ in the sealed sterile bottles. $\mathrm{pH}$ values of all samples were evaluated on $0,1,3$ and 5 days of storage and microbiological analysis were done at the same days. Each experiment was repeated twice on different days, and a total of 112 skin samples were used.

\section{Microbiological analysis and $\mathrm{pH}$ determination}

For each treatment, half of each skin sample was used for microbiological analysis while the other half was used for $\mathrm{pH}$ determination. Each sample was prepared by cutting $10 \mathrm{~g}$ of skin with sterile scissors to use them in microbiological analysis. The samples were placed into a sterile bag containing $90 \mathrm{~mL}$ of sterile peptone $(0.1 \%)$ water and homogenized in a stomacher (LaboratoryBlender 400 Seward, London, U.K.) for 2-3 min. Decimal dilutions were prepared from the skin homogenates by using sterile peptone water after the homogenization. For C. jejuni enumeration, $0.1 \mathrm{~mL}$ volume of each homogenate was plated onto both Blood Free Campylobacter Selective Agar and Palcam Agar (Oxoid CM0877; Supplement SR0155). All plates were incubated for $48-72 \mathrm{~h}$ at $42^{\circ} \mathrm{C}$ in microaerobic conditions and enumerated (Baumgart, 1997). For $\mathrm{pH}$ evaluation, $5 \mathrm{~g}$ of skin sample was weighed in the sterile bag containing $15 \mathrm{~mL}$ of sterile deionized water and homogenized in the stomacher for 2 min (Capita et al., 2002). The $\mathrm{pH}$ values of the samples was measured by electronic $\mathrm{pH}$ meter (Mettler Toledo-Inlab 427, Urdorf, Switzerland). 


\section{Statistical analysis}

Variance analysis in this study were done by the SPSS 10.0 statistical package program (Reference No. 651544). All bacterial counts and each contamination level were converted to $\log _{10} \mathrm{cfu} / \mathrm{g}$-values and the variance analysis was carried out to detect the statistical significance between the effects of antimicrobial treatments on the reduction of C. jejuni and the time of storage period.

\section{RESULTS}

The effects of antimicrobial treatments on the reduction of C. jejuni populations are summarized in Table 1. The microbiological analysis on day 0 of storage showed that compared to the control group, C. jejuni reductions were $1.72 \log$ for $2 \%$ lactic acid and $2.02 \log$ for $3 \%$ lactic acid at the temperature $22^{\circ} \mathrm{C}$. In the group where $4 \%$ lactic acid used, the bacterial counts decreased to undetectable levels $\left(<1.0 \times 10^{2} \mathrm{cfu} / \mathrm{g}\right)$ on day 0 . No reduction was observed in $C$. jejuni levels in the group treated with distilled water at $22^{\circ} \mathrm{C}$ from day 0 to the end of the storage period (day 5). Similar results obtained after using lactic acid solutions at a temperature of $54^{\circ} \mathrm{C}$. Compared to the control group, C. jejuni reductions were 1.91 and $2.34 \log$ for $2 \%$ and $3 \%$ lactic acid, respectively. Bacterial counts were found under the detection limits at 4\% lactic acid treatment group. Also, no reduction was observed in the control group. In other treatments, where hot steam, hot steam and lactic acid combinations were used, the bacterial counts decreased to undetectable levels $(<1.0 \times 102 \mathrm{cfu} / \mathrm{g})$ on day 0 .

In addition to the microbiological analysis, the $\mathrm{pH}$ values of the samples were also measured, while the $\mathrm{pH}$ values of the control samples were found to be 6.43-6.62, whereas the $\mathrm{pH}$ values of the samples treated with lactic acid at concentrations of $2 \%, 3 \%$ and $4 \%$ at $22^{\circ} \mathrm{C}$ and $54^{\circ} \mathrm{C}$ were observed to be low depending on the concentration. The average $\mathrm{pH}$-values of the lactic acid-immersed samples at concentrations of $2 \%$, $3 \%$ and $4 \%, 22^{\circ} \mathrm{C}$ and $54^{\circ} \mathrm{C}$ were measured at the levels of $3.02-3.10,2.97-3.00$ and $2.85-2.88$, respectively, on the $0^{\text {th }}$ day of storage. Also, $\mathrm{pH}$ levels of the samples, monitored to the end of the storage period (data not shown).

Statistical analysis was performed to determine the difference between groups according to the lactic acid concentration in the study. It was determined that the decrease was dependent on the lactic acid concentration and this was statistically significant $(\mathrm{P}<0.005)$.

\section{DISCUSSION}

In our study about 1.72-2.34 $\log$ C. jejuni reduction was detected on day 0 , after the immersion of the samples into the lactic acid solutions at $2 \%$ and $3 \%$ concentrations, at different temperatures $\left(22^{\circ} \mathrm{C}, 54^{\circ} \mathrm{C}\right)$. Also, C. jejuni levels were determined under the detection limits $\left(<1.0 \times 10^{2} \mathrm{cfu} / \mathrm{g}\right)$ when lactic acid and steam used together. The obtained data is similar to the results reported by Chaine et al. (2013). In their study Chaine et al. (2013) determined $3.8 \mathrm{log}$ reduction in Salmonella Enteritidis and C. jejuni levels on chicken skin samples which are treated with 5\% lactic acid solution. Anang et al. (2007) reported that L. monocytogenes, S. Enteritidis and E. coli 0157:H7 levels in poultry meats which are treated with lactic acid, were reduced to $1.97,1.71$ and $2.59 \mathrm{log}$, respectively.

Izat et al. (1990) reported that broilers treated with 1\% and $2 \%$ lactic acid solutions at different stages during processing at different temperatures and different contact times showed reductions on Salmonella levels. Okolocha and Ellerbroek (2005) conducted a study to determine the influence of acid and alkaline treatments on pathogens and the shelf life of poultry meat. Also they compared the spraying and dipping method. Their results showed that

\begin{tabular}{|c|c|c|c|c|c|}
\hline \multicolumn{2}{|c|}{ Treatment groups } & \multicolumn{4}{|c|}{ Days of storage (at $4^{\circ} \mathrm{C}$ ) } \\
\hline & & 0 & 1 & 3 & 5 \\
\hline \multirow[t]{4}{*}{$22^{\circ} \mathrm{C}$} & Control & $4.62 \pm 0.7^{c}$ & $4.55 \pm 0.2^{c}$ & $4.60 \pm 0.4^{c}$ & $4.50 \pm 0.3^{c}$ \\
\hline & $2 \%$ LA & $2.90 \pm 0.4^{b}$ & $<2.0 \pm 0.0^{\mathrm{a}}$ & $<2.0 \pm 0.0^{a}$ & $<2.0 \pm 0.0^{\mathrm{a}}$ \\
\hline & $3 \%$ LA & $2.60 \pm 0.1^{b}$ & $<2.0 \pm 0.0^{\mathrm{a}}$ & $<2.0 \pm 0.0^{\mathrm{a}}$ & $<2.0 \pm 0.0^{\mathrm{a}}$ \\
\hline & $4 \%$ LA & $<2.0 \pm 0.0^{\mathrm{a}}$ & $<2.0 \pm 0.0^{a}$ & $<2.0 \pm 0.0^{a}$ & $<2.0 \pm 0.0^{\mathrm{a}}$ \\
\hline \multirow[t]{7}{*}{$54^{\circ} \mathrm{C}$} & Control & $4.75 \pm 0.9^{c}$ & $4.75 \pm 0.9^{c}$ & $4.74 \pm 0.8^{c}$ & $4.73 \pm 0.7^{c}$ \\
\hline & $2 \%$ LA & $2.84 \pm 0.3^{b}$ & $<2.0 \pm 0.0^{a}$ & $<2.0 \pm 0.0^{a}$ & $<2.0 \pm 0.0^{a}$ \\
\hline & $3 \%$ LA & $2.41 \pm 0.2^{b}$ & $<2.0 \pm 0.0^{a}$ & $<2.0 \pm 0.0^{a}$ & $<2.0 \pm 0.0^{\mathrm{a}}$ \\
\hline & $4 \%$ LA & $<2.0 \pm 0.0^{a}$ & $<2.0 \pm 0.0^{\mathrm{a}}$ & $<2.0 \pm 0.0^{a}$ & $<2.0 \pm 0.0^{\mathrm{a}}$ \\
\hline & $\mathrm{HS}\left(97 \pm 1^{\circ} \mathrm{C}\right), 15 \mathrm{~s}$ & $<2.0 \pm 0.0^{\mathrm{a}}$ & $<2.0 \pm 0.0^{a}$ & $<2.0 \pm 0.0^{a}$ & $<2.0 \pm 0.0^{a}$ \\
\hline & $2 \% \mathrm{LA}+\mathrm{HS}\left(97 \pm 1^{\circ} \mathrm{C}\right), 15 \mathrm{~s}$ & $<2.0 \pm 0.0^{\mathrm{a}}$ & $<2.0 \pm 0.0^{\mathrm{a}}$ & $<2.0 \pm 0.0^{a}$ & $<2.0 \pm 0.0^{a}$ \\
\hline & $\mathrm{HS}\left(133 \pm 1^{\circ} \mathrm{C}\right), 3 \mathrm{~s}$ & $<2.0 \pm 0.0^{\mathrm{a}}$ & $<2.0 \pm 0.0^{a}$ & $<2.0 \pm 0.0^{a}$ & $<2.0 \pm 0.0^{\mathrm{a}}$ \\
\hline
\end{tabular}

Log reduction $=\left(\log _{10} \mathrm{cfu} / \mathrm{g}\right.$ before treatment $)-\left(\log _{10} \mathrm{cfu} / \mathrm{g}\right.$ after treatment). a-c: Different letters within same column are significant $(P<0.005)$. Results are reported as means $(n=23)$. LA, lactic acid; HS, hot steam 
the mean log reductions on the Enterobacteriaceae counts with $1 \%$ lactic acid showed the highest reduction effect on day 0 of storage with a decrease and then a slight increase on days 3 and 6 respectively. Additionally, they indicated that the dipping treatment gave the best overall reduction effect. Anderson and Marshall (1990) reported that, the highest reduction of $S$. Typhimurium was determined when beef samples were dipped in 3\% lactic acid for $15 \mathrm{~s}$. This difference between all these results thought to be due to difference in the application method. Lj et al. (1997) signified the effectiveness of LA treatment was affected by the method of application, and the concentration-time combination.

In our study, it was indicated that in microbiological analyzes performed during different days of storage, the reduction in samples increased during the storage period. In this context, bacterial counts at day 0 were found at countable levels in lactic acid treated groups at concentrations of $2 \%$ and $3 \%$, but below the detection limit at day 1. Researchers (Anderson and Marshall 1990; Mani-Lopez et al., 2012) reported that this was due to the residual effect of lactic acid.

Apart from lactic acid treatments, the effects of hot steam applications on C. jejuni reduction in skin samples were also investigated in this study. For this purpose, $97 \pm 1^{\circ} \mathrm{C}$ and $133 \pm 1^{\circ} \mathrm{C}$ steam was applied to skin samples contaminated with $C$.jejuni for 15 and 3 seconds. C. jejuni was found below the detection limits $(<1.0 \times 102 \mathrm{cfu} / \mathrm{g})$ in both treatments. The results of this study are consistent with the results of Chaine et al. (2013). Indeed, Chaine et al. (2013) reported that $C$. jejuni reduction was approximately $5 \log$ in the wing skin samples after the treatment with steam at $100^{\circ} \mathrm{C}$ for approximately 8 seconds. Similarly, Morgan et al. (1996) and Phebus et al. (1997) reported that hot steam applications significantly reduced the pathogenic microorganisms in cattle carcass and poultry meats. Morgan et al. (1996) reported that steam application in cattle, swine and poultry meat contaminated with Listeria innocua resulted in a reduction of $4 \mathrm{log}$ levels. Phebus et al. (1997) determined a reduction at a level of 4.2-5.3 log after 15 seconds of steaming in cattle meat contaminated with $L$. monocytogenes, E. coli O157: H7 and S. Typhimurium at approximately $5 \log \mathrm{cfu} / \mathrm{cm}^{2}$. Likewise, Özdemir et al. (2006) reported a reduction in $S$. Typhimurium and Listeria monocytogenes counts at $0.54-0.09 \log$ immediately after treatment in cattle meat immersed in hot water at $82^{\circ} \mathrm{C}$ for 15 seconds, respectively.

\section{CONCLUSIONS}

It was determined that decontamination with lactic acid and hot steam application had a significant reduction effect on C.jejuni in chicken skin samples and the effect of lactic acid was increased depending on the concentration. For this reason, both lactic acid and hot steam treatments are considered to be important for the reduction of C. jejuni, which is primarily responsible for foodborne infections, and for the production of safe poultry meat in terms of public health.

\section{Authors' contributions}

Haydar Ozdemir conceived and planned the experiments and he supervised the work. Gorkem Cengiz and Erdi Sen verified the methods and carried out the experiments. Guzin Iplikcioglu Cil, and Bahar Onaran contributed to the interpretation of the results. Haydar Ozdemir, took the lead in writing the manuscript. Guzin Iplikcioglu Cil, and Bahar Onaran wrote the paper with input from all authors and prepared the manuscript according to the journal.

\section{REFERENCES}

Anang, D. M., Rusul, G., Bakar, J., \& Ling, F. H. (2007). Effects of lactic acid and lauricidin on the survival of Listeria monocytogenes, Salmonella enteritidis and Escherichia coli O157: $\mathrm{H} 7$ in chicken breast stored at 4 C. Food Control, 18(8), 961-969.

Anderson, M. E., \& Marshall, R. T. (1990). Reducing microbial populations on beef tissues: Concentration and temperature of an acid mixture. Journal of Food Science, 55(4), 903-905.

Anon (2013). Commission Regulation (EU) No 101/2013 of 4 February 2013. Concerning the use of lactic acid to reduce microbiological surface contamination on bovine carcasses. From: https://eurlex.europa.eu/legal-content/EN/TXT/PDF/?uri=CELEX:32013R $0101 \&$ from $=E N$

Anon (2015). USDA/FSIS Directive 7120.1, Revision 30, October 21. Safe and Suitable Ingredients Used in the Production of Meat, Poultry, and Egg Products. From: https://www.fsis.usda.gov/ wps/portal/fsis/topics/regulations/directives/7000-series/safesuitable-ingredients-related-document

Baumgart J (1997). Mikrobiologische Unterschungen von Lebensmitteln. Behr's Verlag, Robert Seeman GmbH\&Co, Hamburg.

Bolder, N. M. (1997). Decontamination of meat and poultry carcasses. Trends in Food Science \& Technology, 8(7), 221-227.

Capita, R., Alonso-Calleja, C., del Camino García-Fernández, M., \& Moreno, B. (2002). Activity of trisodium phosphate compared with sodium hydroxide wash solutions against Listeria monocytogenes attached to chicken skin during refrigerated storage. Food Microbiology, 19(1), 57-63.

Chaine, A., Arnaud, E., Kondjoyan, A., Collignan, A., \& Sarter, S. (2013). Effect of steam and lactic acid treatments on the survival of Salmonella Enteritidis and Campylobacter jejuni inoculated on chicken skin. International journal of Food Microbiology, 162(3), 276-282.

Hashem, F., \& Parveen, S. (2016). Salmonella and Campylobacter: Antimicrobial resistance and bacteriophage control in poultry. Food Microbiology, 53, 104-109.

Hue, O., Allain, V., Laisney, M. J., Le Bouquin, S., Lalande, F., Petetin, I., Rouxel, S., Quesne, S., Gloaguen, P. Y., Picherot, M., Santolini, J., Bougeard, S., Salvat, G., \& Chemaly, M. (2011). Campylobacter contamination of broiler caeca and carcasses 
at the slaughterhouse and correlation with Salmonella contamination. Food Microbiology, 28(5), 862-868.

Izat, A. L., Colberg, M., Thomas, R. A., Adams, M. H., \& Driggers, C. D. (1990). Effects of lactic acid in processing waters on the incidence of Salmonellae on broilers. Journal of Food Quality, 13(4), 295-306

Koluman, A. (2010). Piliç Kümesleri ve Kesimhanelerinde Campylobacter jejuni Kontaminasyonunun Belirlenmesi. Türk Hijyen ve Deneysel Biyoloji Dergisi, 67(2), 57-64.

Liu, A., Peng, Z., Zou, L., Zhou, K., Ao, X., He, L., Shujuan, C., \& Liu, S. (2016). The effects of lactic acid-based spray washing on bacterial profile and quality of chicken carcasses. Food Control, 60, 615-620.

Lj, Y., Slavik, M. F., Walker, J. T., \& Xiong, H. (1997). science, 62(3), 605-607. Pre-chill spray of chicken carcasses to reduce Salmonella Typhimurium. Journal of Food Science, 62(3), 605-607.

Ma, L., Wang, Y., Shen, J., Zhang, Q., \& Wu, C. (2014). Tracking Campylobacter contamination along a broiler chicken production chain from the farm level to retail in China. International Journal of Food microbiology, 181, 77-84.

Mani-Lopez, E., García, H. S., \& López-Malo, A. (2012). Organic acids as antimicrobials to control Salmonella in meat and poultry products. Food Research International, 45(2), 713-721.

Morgan, A. I., Goldberg, N., Radewonuk, E. R., \& Scullen, O. J. (1996). Surface pasteurization of raw poultry meat by steam. LWT-Food Science and Technology, 29(5-6), 447-451.

Oezdemir, H., Gücükoğlu, A., \& Koluman, A. (2006). Acidified sodium chlorite, trisodium phosphate and populations of Campylobacter jejuni on chicken breast skin. Journal of Food Processing and Preservation, 30(5), 608-615.

Okolocha, E. C., \& Ellerbroek, L. (2005). The influence of acid and alkaline treatments on pathogens and the shelf life of poultry meat. Food Control, 16(3), 217-225.

Özdemir, H., Yıldırım, Y., Küplülü, Ö., Koluman, A., Göncüoğlu, M., \& İnat, G. (2006). Effects of lactic acid and hot water treatments on Salmonella Typhimurium and Listeria monocytogenes on beef. Food Control, 17(4), 299-303.

Phebus, R. K., Nutsch, A. L., Schafer, D. E., Wilson, R. C., Riemann, M. J., Leising, J. D., Kastner, C. L., Wolf, J. R., \& Prasai, R. K. (1997). Comparison of steam pasteurization and other methods for reduction of pathogens on surfaces of freshly slaughtered beef. Journal of Food Protection, 60(5), 476-484.

Savaçı, M., \& Oezdemir, H (2006). Prevalence of thermophilic Campylobacter spp. in retail chicken meat in Ankara. Journal of Food Safety, 26(3): 244-250.

Skarp, C. P. A., Hänninen, M. L., \& Rautelin, H. I. K. (2016). Campylobacteriosis: the role of poultry meat. Clinical Microbiology and Infection, 22(2), 103-109.

Sofos, J. N., \& Smith, G. C. (1998). Nonacid meat decontamination technologies: Model studies and commercial applications. International Journal of Food Microbiology, 44(3), 171-188.

Wieczorek, K., \& Osek, J. (2015). A five-year study on prevalence and antimicrobial resistance of Campylobacter from poultry carcasses in Poland. Food microbiology, 49, 161-16. 